\title{
Sugar beet profits from intercropping with wheat both under optimum and deficient phosphorus supply
}

\author{
Roghieh HAJIBOLAND* ${ }^{1}$, Shirin SHEKARI ${ }^{2}$, Noushin SADEGHZADEH ${ }^{2}$, Charlotte POSCHENRIEDER ${ }^{3}$ \\ Received November 03, 2017; accepted January 16, 2018. \\ Delo je prispelo 03. novembraa 2017, sprejeto 16. Januarja 2018.
}

\begin{abstract}
An experiment was conducted with wheat and sugar beet as monocrop and intercrop under low or adequate phosphorus supply. Dry matter production of shoot and roots were decreased in wheat while increased in sugar beet under intercrop conditions. Photosynthesis rate was diminished under intercrop conditions in wheat while elevated in sugar beet concomitant with reduction of transpiration rate and higher water use efficiency in the latter species. Phosphorus, potassium and iron contents were also lower in intercrop wheat while increased in sugar beet. The same effect of intercropping on biomass and nutrients uptake was observed in the short term hydroponic experiment. Interestingly, three root parameters including length, soluble carbohydrates and activity of secretory acid phosphatase that are characteristics for phosphorus-deficient plants were enhanced in both species by intercropping irrespective the phosphorus supply level. These data suggested an interspecific interaction beyond the different nutrient acquisition capacity in the intercrop pots.
\end{abstract}

Key words: intercrop; monocrop; sugar beet; wheat; phosphorus deficiency; acid phosphatase

\section{IZVLEČEK}

\section{SLADKORNA PESA USPEVA BOLJE KOT PŠENICA V MEDSETVI V RAZMERAH OPTIMALNE IN POMANKLJIVE PRESKRBE S FOSFORJEM}

$\mathrm{V}$ raziskavi je bil opravljen poskus s pšenico in sladkorno peso $\mathrm{v}$ čisti kulturi in medsetvi v razmerah primerne in pomankljive preskrbe $\mathrm{s}$ fosforjem. $\mathrm{V}$ razmerah medsetve sta se biomasi korenin in poganjkov zmanšali pri pšenici a povečali pri sladkorni pesi. Podobno se je pri pšenici v medsetvi zmanjšala fotosinteza in povečala pri sladkorni pesi $\mathrm{s}$ hkratnim zmanjšanjem transpiracije in večjo učinkovitostjo izrabe vode. Pravtako so bile vsebnost fosforja, kalija in železa manjše pri pšenici v medsetvi in večje pri sladkorni pesi. Podoben učinek medsetve na biomaso in vsebnost hranil je bil opazen $\mathrm{v}$ kratkotrajnem hidroponskem poskusu. Zanimivo je, da so se neglede na preskrbo $\mathrm{s}$ fosforjem $\mathrm{v}$ medsetvi pri obeh vrstah povečali parametri korenin kot so njihova dolžina, vsebnost topnih ogljikovih hidratov in aktivnost izločenih kislih fosfataz, kar je značilnost rastlin, ki rastejo v pomanjkanju fosforja. Podatki nakazujejo na medvrstne interakcije, ki presegajo razlike $\mathrm{v}$ sposobnosti privzema hranil $\mathrm{v}$ lončnem poskusu z medsetvijo.

Ključne besede: medsetev; čista kultura; sladkorna pesa; pšenica; pomanjkanje fosforja; kisle fosfataze

\footnotetext{
1 Professor of Plant Physiology, Department of Plant Science, Faculty of Natural Sciences, University of Tabriz, 51666-16471 Tabriz, Iran; *Corresponding author: ehsan@tabrizu.ac.ir

2 M.Sc. of Plant Physiology, Department of Plant Science, Faculty of Natural Sciences, University of Tabriz, 51666-16471 Tabriz, Iran

3 Professor of Plant Physiology, Plant Physiology Lab, Bioscience Faculty, Universidad Autonoma de Barcelona, 08193 Bellaterra, Spain
}

This paper is part of a MSc thesis of S.S. under supervision of R.H. 


\section{INTRODUCTION}

Crop plants are cultivated mainly as monocultures. Monocropping facilitates agricultural practices such as weed removing and harvest. However, this system maintains crop productivity through heavy chemical inputs including fertilizers and pesticides and reduces the plant and microorganism diversity (Brooker et al., 2015). Intercropping, in which at least two crop species are grown on the same plot of land simultaneously, results in higher yield under different environmental and soil conditions (Brooker et al., 2015; Li et al., 2014). Indeed, in intercropping systems both negative interaction (competition) and positive interaction (facilitation) can occur simultaneously. Competition prevents crop growth by sharing the limited resources or allelopathy, whereas facilitation promotes crop performance by improving the micro-environment for utilizing resources (Zhang \& Li, 2003; Li et al., 2014; Brooker et al., 2015).

Phosphorus (P) deficiency is a widespread nutritional disorder in crop plants (Hawkesford et al., 2012). In soil solution, $\mathrm{P}$ mostly exists as $\mathrm{H}_{2} \mathrm{PO}_{4}{ }^{-}$but its fixation to the soil particles and minerals is very important factor determining its availability for plant roots. Thus, spatial availability of roots to soil $\mathrm{P}$ resources is an important criterion for plants $\mathrm{P}$ uptake capacity. Every factor that changes root morphology in favor of higher spatial exploration of the soil profile can facilitates $\mathrm{P}$ acquisition capacity in plants (Hawkesford et al., 2012).

Interspecific interactions consist of both above and below-ground interactions (Zhang et al., 2001). Increasing evidence from studies on intercropping systems indicate that root interactions are more important than shoot interactions for determining crop productivity and intercropping advantages (Wu et al., 2012). In low-input agroecosystems, the productivity of cultivated land will primarily depend on the availability of soil resources. Thus, facilitative root interactions in mixed cropping systems are important for the nutritional improvement of crops in nutrient-poor soils (Zhang et al., 2010; Wu et al., 2012). Understanding interspecific below-ground interactions between crops is crucial to promote sustainable production (Brooker et al., 2008; Wu et al., 2012).

Rhizosphere effects contribute significantly to the improved $\mathrm{P}$ and $\mathrm{Fe}$ uptake under field conditions (Neumann \& Römheld, 2012). It has been shown that intercropping legumes and cereals improves the $\mathrm{Fe}$ nutrition of both species because of higher ferric chelate reductase activity in the rizosphere of legumes and excretion of phytosiderophores into the rhizosphere of Gramineae that are particularly effective in noncalcareous and calcareous conditions, respectively (Zuo \& Zhang, 2009; Li et al., 2014). Legumes when intercropped with cereals facilitate the P uptake through acidification of the rhizosphere, exudation of carboxylates and flavonoids, and root secretion of acid phosphatase in P-deficient soils (Li et al., 2007; Li et al., 2014; Dissanayaka et al., 2015). Most of the works on interspecific interactions between crops have focused on cereal-cereal and particularly on legume-based intercropping systems. Knowledge is lacking on interspecific interactions in the intercropping cereals with other dicotyledonous species.

In order to study the physiological interactions in an intercropping system, a sugar beet-wheat intercropping experiment was conducted at low and adequate P supply levels under growth chamber conditions. In addition of dry matter production and photosynthesis, nutrients uptake capacity and rhizosphere properties were studied under monocropping and intercropping systems. In order to evaluate the effect of spatial availability and a better interpretation of uptake data, a short-term hydroponic experiment was also conducted as monocrop and intercrop cultures.

\section{MATERIALS AND METHODS}

Seeds of wheat (Triticum aestivum 'Homa') plants were provided by Dryland Agricultural Research Institute (DARI) (Maragheh, Iran), and of sugar beet (Beta vulgaris 'IC') by Agricultural Research Institute, WestAzarbaijan Province, Iran.

\subsection{Plants culture and treatments}

Seeds were surface-sterilized with $1 \%$ active hypochlorite and germinated in dark. Young seedlings were transferred to the light. Five-day-old sugar beet seedlings were pre-cultured in $50 \%$ Hoagland nutrient solution for one month. Thereafter, 35-day-old sugar beet together with seven-day-old wheat seedlings with similar size of shoot and roots were transferred to two liter plastic pots filled with washed perlite and irrigated with $100 \%$ Hoagland nutrient solution at field capacity after daily weighing. Wheat and sugar beet were cultivated either as monocrop (MC) or intercrop (IC). Four plants were cultivated in each MC pot and two plants of each species in IC pots. The amount of nutrient solution used for irrigation was $100 \mathrm{ml} \mathrm{week}^{-1} \mathrm{l}^{-1}$ at the first 4 weeks and increased to the $200 \mathrm{ml} \mathrm{week}^{-1} \mathrm{l}^{-1}$ 
during further growth stage. Irrigation was performed after daily weighing and water was used as interval if necessary. Two different $\mathrm{P}$ supply levels including adequate $(2 \mathrm{mM})$ and low $(0.2 \mathrm{mM}) \mathrm{P}$ were applied immediately after transferring plants to the pots. Different $\mathrm{P}$ levels in the nutrient solution were provided through reduction of $\mathrm{NH}_{4} \mathrm{H}_{2} \mathrm{PO}_{4}$ in the nutrient solution. In order to equilibrate $\mathrm{NH}_{4}^{+}$concentration between two $\mathrm{P}$ treatments, $1.8 \mathrm{mM} \mathrm{NH}_{4} \mathrm{Cl}$ was added to the low $\mathrm{P}$ nutrient solution.

Plants were grown under growth chamber conditions with a day/night temperature regime of $25-28 / 15-17^{\circ} \mathrm{C}$, a relative humidity of $70 / 80 \%$ and a photoperiod of $17 / 7 \mathrm{~h}$ at a photon flux density of about $300 \mu \mathrm{mol} \mathrm{m}^{-2} \mathrm{~s}^{-1}$ provided by fluorescent lamps. Before harvest, net photosynthesis rate were determined in the attached leaves using a calibrated portable gas exchange system (LCA-4, ADC Bioscientific Ltd., UK) during the light period between 9:00 and 13:00 under a photon flux density of about $300 \mu \mathrm{mol} \mathrm{m}^{-2} \mathrm{~s}^{-1}$.

\subsection{Plants harvest and determination of elements}

Ten weeks after transferring to the pots and starting different $\mathrm{P}$ treatments, plants were harvested. Shoot and roots were separated, roots were washed with distilled water and blotted dry on filter paper and their fresh mass (FM) were determined. Plants dry mass (DM) was determined after drying in $70{ }^{\circ} \mathrm{C}$ for $48 \mathrm{~h}$. Subsamples from leaves and roots were taken for biochemical analyses before drying.

For determination of $\mathrm{P}, \mathrm{K}$ and $\mathrm{Fe}$ concentrations, oven dried leaf samples were ashed in a muffle furnace at $550^{\circ} \mathrm{C}$ for eight hours, resolved in $\mathrm{HCl}$, and made up to volume by distilled water. Concentration of $\mathrm{P}$ was determined using ammonium molybdate-vanadate colorimetric method (Jaiswal, 2004). Concentrations of $\mathrm{K}$ and $\mathrm{Fe}$ were determined by flame photometry (PFP7, Jenway, UK) and atomic absorption spectrometry (AA6300, Shimadzu, Japan), respectively.

In addition of elements concentration in shoot and root, the proportion $(\%)$ of elements taken up by plant, i.e. the ratio of plants element content to that added to the medium throughout the experiment, was calculated for $\mathrm{P}$ and $\mathrm{K}$.

\subsection{Assay of rhizosphere $\mathrm{pH}$ and root acid phosphatase activity}

At harvest, roots were shaken gently to collect loosely attached perlite particles defined as rhizosphere (Bagayoko et al., 2000). These perlite samples with a volume of one $\mathrm{ml}$ were suspended immediately in the same volume of distilled water and shaken vigorously for $30 \mathrm{~min}$. After centrifugation, $\mathrm{pH}$ was determined in the supernatant.

For determination of secretory acid phosphatase (APase) activity, root segments $(2 \mathrm{~cm})$ were excised from apical root zone (without root tips) of the firstorder laterals and washed twice with distilled water for 5 min. Root segments were treated with incubation medium containing $0.5 \mathrm{ml}$ distilled water, $0.4 \mathrm{ml} \mathrm{Na}$ acetate buffer (200 mM, pH 5.2) and $0.1 \mathrm{ml} \mathrm{p}$ nitrophenyl phosphate (NPP, $150 \mathrm{mM}$ ) for one min at $25-30{ }^{\circ} \mathrm{C}$. Thereafter, $0.8 \mathrm{ml}$ of the reaction media was mixed with $0.4 \mathrm{ml}$ of $500 \mathrm{mM} \mathrm{NaOH}$ to terminate the reaction. The absorption of the dephosphorylation product, $p$-nitrophenol (PNP), was determined spectrophotometrically at $405 \mathrm{~nm}$ (Wang et al., 2015).

\subsection{Biochemical determinations}

Leaf concentration of chlorophylls (Chl) a, b and carotenoids (Car) were determined according to Lichtenthaler and Wellburn (1985). For determination of non-structural carbohydrates, samples were homogenized in $100 \mathrm{mM}$ phosphate buffer $(\mathrm{pH} 7.5)$ at $4{ }^{\circ} \mathrm{C}$, after centrifugation at $12000 \mathrm{~g}$ for $15 \mathrm{~min}$, supernatant was used for determination of total soluble sugars whereas the pellets were kept for starch analysis (Yemm \& Willis, 1954). Soluble protein concentration was determined using a commercial reagent (Bradford reagent, Sigma, St. Louis, USA) and bovine albumin serum (BSA, Merck, Darmstadt, Germany) as standard. Content of total free $\alpha$-amino acids was assayed using a ninhydrin colorimetric method (Yemm \& Cocking, 1955) with glycine (Merck, Darmstadt, Germany) as standard.

\subsection{Hydroponic experiment}

Thirty five-day-old sugar beet seedlings together with seven-day-old wheat seedlings were transferred to one liter plastic pots (4 plants in each pot; 2-2 in intercrop) filled with aerated $100 \%$ Hoagland nutrient solution and grown under growth chamber conditions. One group of plants were harvested one week after transferring to the pots and analyzed for biomass and nutrients content as described above. The second group was grown for ten weeks before harvest, and during this time nutrient solutions were replaced every 5 days.

\subsection{Experimental design and statistical analyses}

The experiments were undertaken in randomized block design with four replications as four independent pots. Differences between the means were detected according to Tukey's test $(p<0.05)$ using Sigma Stat 2.03 software. 


\section{RESULTS}

Growth parameters were influenced significantly under IC conditions in both species. In wheat, shoot biomass was decreased by IC while increased in sugar beet at both $\mathrm{P}$ supply levels significantly. In wheat, root mass decreased by intercropping only in low $\mathrm{P}$ plants while root length was significantly increased under these conditions. In sugar beet, similar to shoot growth, root mass and length both were higher in IC than MC, irrespective the P supply level (Fig. 1).
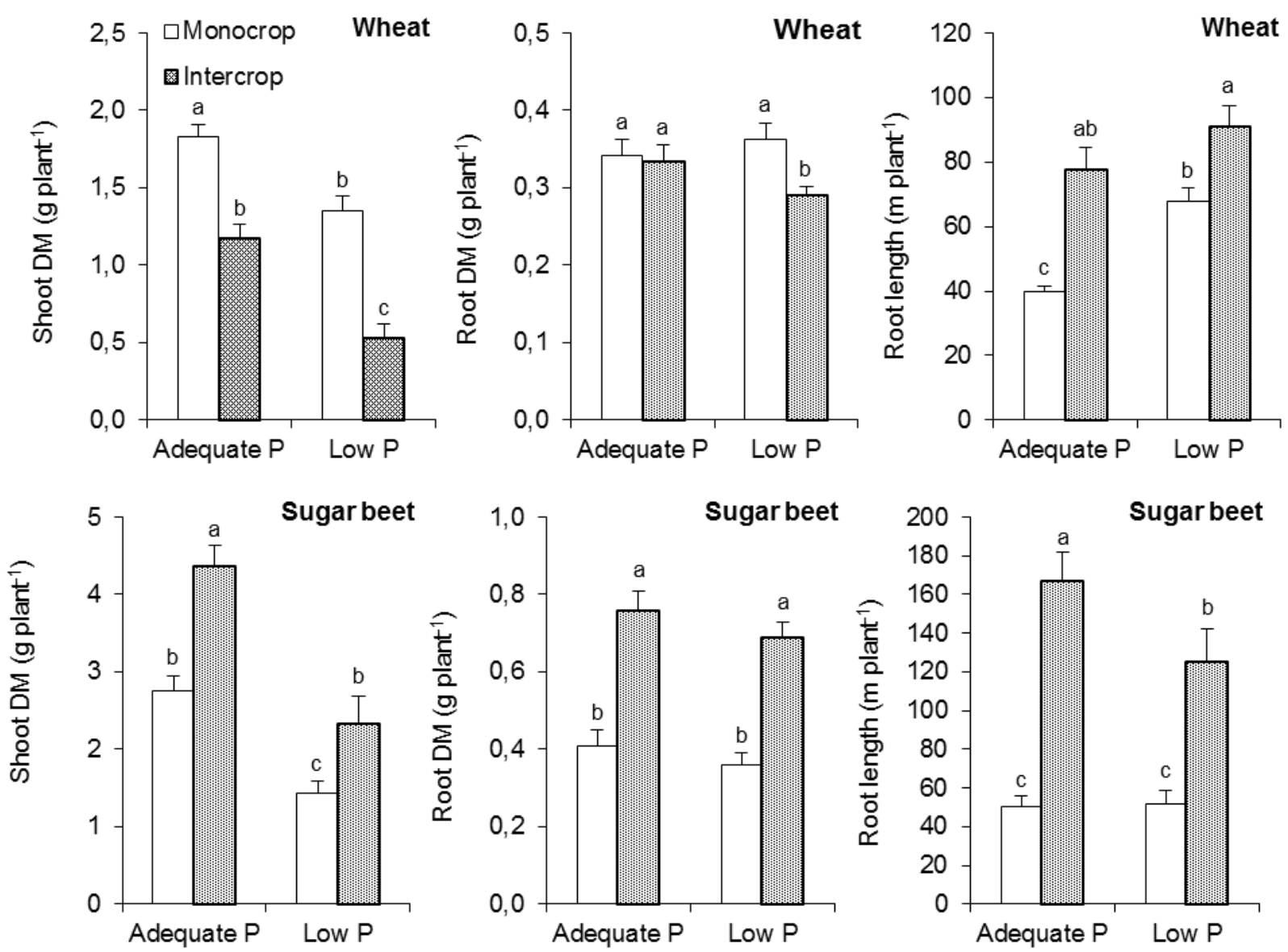

Figure 1: Shoot and root dry mass (DM) and root length in wheat and sugar beet plants in monocropping and intercropping under adequate or low $\mathrm{P}$ supply. Bars indicated by the same letter are not statistically different $(p<$ $0.05)$.

Leaf concentrations of Chls and Car decreased under IC conditions in wheat under both $\mathrm{P}$ supply levels, while these parameters were not affected in sugar beet, except Car in P-deficient plants. P deficiency, however, caused a significant reduction of $\mathrm{Chl} a$ in sugar beet and $\mathrm{Chl} \mathrm{b}$ in wheat under both cropping systems (Table 1). Net photosynthesis rate was expectedly lower under $\mathrm{P}$ deficiency conditions in both species. Intercropping, however, increased photosynthesis in sugar beet under both $\mathrm{P}$ supply levels while decreased it in wheat. A statistically significant reduction of the transpiration rate due to P deficiency was only observed in sugar beet in MC. Intercropping tended to decrease the transpiration rates in both species regardless the $\mathrm{P}$ supply, but a statistically significant influence was only observed in sugar beet under adequate $\mathrm{P}$ supply. Instant water use efficiency (WUE) was not influenced in wheat plants either by $\mathrm{P}$ supply or IC, while in sugar beet it was significantly higher in IC plants irrespective the $\mathrm{P}$ supply level (Table 1). 
Table 1: Leaf concentration of chlorophyll a, b and carotenoids ( $\left.\mathrm{mg} \mathrm{g}^{-1} \mathrm{FM}\right)$, net photosynthesis rate $\left(\mu \mathrm{mol} \mathrm{CO}_{2} \mathrm{~m}^{-2}\right.$ $\left.\mathrm{s}^{-1}\right)$, transpiration rate $\left(\mathrm{mmol} \mathrm{H}_{2} \mathrm{O} \mathrm{m}^{-2} \mathrm{~s}^{-1}\right)$ and instant water use efficiency (iWUE, $\mu \mathrm{mol} \mathrm{mmol}{ }^{-1}$ ) in wheat and sugar beet plants in monocropping (MC) or intercropping (IC) in perlite at adequate or low P supply for 10 weeks under controlled environmental conditions.

\begin{tabular}{|c|c|c|c|c|c|c|c|}
\hline \multirow{2}{*}{$\begin{array}{l}\text { Plant } \\
\text { species }\end{array}$} & \multirow{2}{*}{$\begin{array}{l}\text { Culture } \\
\text { mode }\end{array}$} & \multicolumn{2}{|l|}{ Chl $a$} & \multicolumn{2}{|l|}{ Chl $b$} & \multicolumn{2}{|l|}{ Car } \\
\hline & & Adequate $\mathrm{P}$ & Low $\mathrm{P}$ & Adequate $\mathrm{P}$ & Low $\mathrm{P}$ & Adequate $\mathrm{P}$ & Low $\mathrm{P}$ \\
\hline \multirow{2}{*}{ Wheat } & MC & $1.98 \pm 0.22^{a}$ & $1.85 \pm 0.29^{\mathrm{a}}$ & $1.18 \pm 0.13^{a}$ & $0.99 \pm 0.17^{b}$ & $0.19 \pm 0.04^{\mathrm{a}}$ & $0.22 \pm 0.05^{\mathrm{a}}$ \\
\hline & IC & $1.49 \pm 0.10^{b}$ & $1.20 \pm 0.16^{\mathrm{b}}$ & $0.62 \pm 0.05^{\mathrm{c}}$ & $0.49 \pm 0.06^{c}$ & $0.09 \pm 0.02^{b}$ & $0.12 \pm 0.01^{\mathrm{b}}$ \\
\hline \multirow{4}{*}{ Sugar beet } & $\mathrm{MC}$ & $1.54 \pm 0.32^{\mathrm{a}}$ & $0.89 \pm 0.02^{b}$ & $0.68 \pm 0.11^{\mathrm{a}}$ & $0.69 \pm 0.50^{\mathrm{a}}$ & $0.25 \pm 0.06^{\mathrm{a}}$ & $0.21 \pm 0.01^{a b}$ \\
\hline & IC & $1.72 \pm 0.11^{\mathrm{a}}$ & $0.90 \pm 0.09^{b}$ & $0.62 \pm 0.02^{\mathrm{a}}$ & $1.06 \pm 0.08^{\mathrm{a}}$ & $0.26 \pm 0.04^{\mathrm{a}}$ & $0.12 \pm 0.06^{\mathrm{b}}$ \\
\hline & & \multicolumn{2}{|c|}{ Photosynthesis rate } & \multicolumn{2}{|c|}{ Transpiration rate } & \multicolumn{2}{|l|}{$i W U E$} \\
\hline & & Adequate $\mathrm{P}$ & Low $\mathrm{P}$ & Adequate $\mathrm{P}$ & Low $\mathrm{P}$ & Adequate $\mathrm{P}$ & Low $\mathrm{P}$ \\
\hline \multirow{2}{*}{ Wheat } & $\mathrm{MC}$ & $7.27 \pm 0.40^{\mathrm{a}}$ & $6.17 \pm 0.57^{b}$ & $2.04 \pm 0.34^{\mathrm{a}}$ & $2.12 \pm 0.30^{\mathrm{a}}$ & $3.39 \pm 0.51^{\mathrm{a}}$ & $2.96 \pm 0.20^{\mathrm{a}}$ \\
\hline & IC & $5.50 \pm 0.59^{\mathrm{b}}$ & $4.12 \pm 0.41^{\mathrm{c}}$ & $1.51 \pm 0.54^{\mathrm{a}}$ & $1.52 \pm 0.18^{\mathrm{a}}$ & $3.48 \pm 0.75^{\mathrm{a}}$ & $2.73 \pm 0.59^{\mathrm{a}}$ \\
\hline \multirow{2}{*}{ Sugar beet } & $\mathrm{MC}$ & $4.58 \pm 0.70^{b}$ & $3.53 \pm 0.16^{\mathrm{c}}$ & $2.53 \pm 0.29^{a}$ & $1.75 \pm 0.41^{b}$ & $1.81 \pm 0.15^{b}$ & $1.21 \pm 0.47^{b}$ \\
\hline & IC & $5.65 \pm 0.37^{\mathrm{a}}$ & $4.48 \pm 0.18^{b}$ & $1.59 \pm 0.23^{b}$ & $1.23 \pm 0.10^{\mathrm{b}}$ & $3.48 \pm 0.44^{\mathrm{a}}$ & $3.44 \pm 0.60^{\mathrm{a}}$ \\
\hline
\end{tabular}

Data of each parameter within each plant species indicated by the same letter are not statistically different $(p<0.05)$.

Leaf concentrations of soluble sugars were expectedly higher in $\mathrm{P}$ deficient plants. This effect was significant for both species except for sugar beet under IC conditions. Intercropping increased the concentrations of soluble sugars in both species regardless the P level except for sugar beet under low $\mathrm{P}$ conditions. In wheat, soluble sugar concentration of roots was lower in MC plants at low $\mathrm{P}$ conditions. Intercropped plants had higher root soluble sugars in sugar beet under both $\mathrm{P}$ nutritional conditions, this effect was observed in wheat only under low supply of $\mathrm{P}$ (Table 2). Starch concentrations in the leaves and roots of sugar beet were affected by neither P nutrition nor IC. In wheat, starch increased in the leaves by IC under sufficient $\mathrm{P}$ supply (Table 2).

Table 2: Concentration ( $\mathrm{mg} \mathrm{g}^{-1} \mathrm{FM}$ ) of soluble sugars and starch in wheat and sugar beet plants in monocropping (MC) or intercropping (IC) in perlite at adequate or low P supply for 10 weeks under controlled environmental conditions.

\begin{tabular}{llllll}
\hline \multirow{2}{*}{ Plant species } & \multirow{2}{*}{$\begin{array}{l}\text { Culture } \\
\text { mode }\end{array}$} & \multicolumn{3}{l}{ Soluble sugars } & Starch \\
\cline { 3 - 5 } & & Adequate P & Low P & Adequate P & Low P \\
\cline { 2 - 5 } Wheat & MC & $7.9 \pm 2.62^{\mathrm{c}}$ & $19.4 \pm 5.23^{\mathrm{b}}$ & $0.17 \pm 0.01^{\mathrm{b}}$ & $0.15 \pm 0.01^{\mathrm{b}}$ \\
& IC & $14.5 \pm 3.47^{\mathrm{b}}$ & $26.4 \pm 1.82^{\mathrm{a}}$ & $0.23 \pm 0.01^{\mathrm{a}}$ & $0.15 \pm 0.02^{\mathrm{b}}$ \\
\hline \multirow{2}{*}{ Sugar beet } & MC & $5.43 \pm 0.61^{\mathrm{b}}$ & $12.9 \pm 2.79^{\mathrm{a}}$ & $0.46 \pm 0.04^{\mathrm{a}}$ & $0.58 \pm 0.19^{\mathrm{a}}$ \\
& IC & $14.1 \pm 1.65^{\mathrm{a}}$ & $14.4 \pm 1.89^{\mathrm{a}}$ & $0.41 \pm 0.04^{\mathrm{a}}$ & $0.59 \pm 0.13^{\mathrm{a}}$ \\
\hline \multirow{2}{*}{ Wheat } & MC & Root & & & \\
\hline \multirow{2}{*}{ Sugar beet } & IC & $7.52 \pm 1.54^{\mathrm{a}}$ & $4.51 \pm 1.47^{\mathrm{b}}$ & $0.09 \pm 0.03^{\mathrm{a}}$ & $0.03 \pm 0.00^{\mathrm{b}}$ \\
& MC & $5.90 \pm 0.99^{\mathrm{a}}$ & $9.05 \pm 0.97^{\mathrm{a}}$ & $0.08 \pm 0.01^{\mathrm{a}}$ & $0.05 \pm 0.01^{\mathrm{b}}$ \\
\hline & IC & $8.32 \pm 0.87^{\mathrm{b}}$ & $4.77 \pm 0.44^{\mathrm{c}}$ & $0.24 \pm 0.15^{\mathrm{a}}$ & $0.36 \pm 0.01^{\mathrm{a}}$ \\
& & $11.15 \pm 0.10^{\mathrm{a}}$ & $0.24 \pm 0.12^{\mathrm{a}}$ & $0.28 \pm 0.03^{\mathrm{a}}$ \\
\hline
\end{tabular}

Data of each parameter within each plant species indicated by the same letter are not statistically different $(p<0.05)$.

In the leaves, total leaf amino acid concentrations were lower in IC wheat at both P supply levels, while in sugar beet it increased by IC in P-deficient plants. Soluble protein concentrations in the leaves were not affected by IC in sugar beet, while they decreased in wheat at low $\mathrm{P}$ level. Low P supply resulted in higher leaf amino acid concentrations while in sugar beet rather a decrease was observed under these conditions (Table 3). In the roots, amino acid concentrations were not affected by $\mathrm{P}$ supply, but protein concentrations decreased significantly in both species under MC conditions. Intercropping decreased significantly amino acids and protein concentrations in wheat. Negative effects of IC on these parameters were not observed in sugar beet and a significant increase of soluble proteins upon IC was found in low P plants (Table 3). 
Roghieh HAJIBOLAND et al.

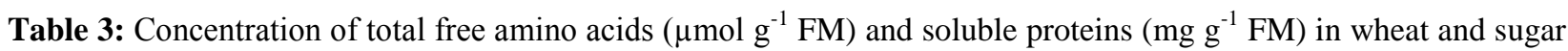
beet plants in monocropping (MC) or intercropping (IC) in perlite at adequate or low $\mathrm{P}$ supply for 10 weeks under controlled environmental conditions.

\begin{tabular}{|c|c|c|c|c|c|}
\hline \multirow{3}{*}{$\begin{array}{l}\text { Plant } \\
\text { species }\end{array}$} & \multirow{3}{*}{$\begin{array}{l}\text { Culture } \\
\text { mode }\end{array}$} & \multicolumn{2}{|l|}{ Amino acids } & \multicolumn{2}{|c|}{ Soluble proteins } \\
\hline & & Adequate $\mathrm{P}$ & Low $\mathrm{P}$ & Adequate $\mathrm{P}$ & Low $\mathrm{P}$ \\
\hline & & Shoot & & & \\
\hline \multirow{2}{*}{ Wheat } & $\mathrm{MC}$ & $10.0 \pm 1.90^{b}$ & $20.9 \pm 2.63^{a}$ & $2.04 \pm 0.59^{\mathrm{a}}$ & $1.73 \pm 0.38^{\mathrm{a}}$ \\
\hline & IC & $7.6 \pm 1.48^{b}$ & $8.9 \pm 1.10^{\mathrm{b}}$ & $1.53 \pm 0.18^{\mathrm{ab}}$ & $0.91 \pm 0.40^{b}$ \\
\hline \multirow{3}{*}{ Sugar beet } & $\mathrm{MC}$ & $5.0 \pm 0.54^{\mathrm{a}}$ & $2.3 \pm 0.23^{b}$ & $2.13 \pm 0.78^{\mathrm{a}}$ & $1.99 \pm 0.14^{\mathrm{a}}$ \\
\hline & IC & $3.9 \pm 0.72^{\mathrm{a}}$ & $5.9 \pm 1.06^{\mathrm{a}}$ & $2.62 \pm 0.07^{\mathrm{a}}$ & $2.13 \pm 0.23^{\mathrm{a}}$ \\
\hline & & Root & & & \\
\hline \multirow{2}{*}{ Wheat } & $\mathrm{MC}$ & $4.7 \pm 1.24^{\mathrm{a}}$ & $4.62 \pm 1.24^{\mathrm{a}}$ & $0.74 \pm 0.16^{\mathrm{a}}$ & $0.36 \pm 0.03^{b}$ \\
\hline & IC & $3.0 \pm 0.68^{b}$ & $2.90 \pm 0.35^{b}$ & $0.13 \pm 0.01^{\mathrm{c}}$ & $0.16 \pm 0.02^{\mathrm{c}}$ \\
\hline \multirow{2}{*}{ Sugar beet } & $\mathrm{MC}$ & $1.1 \pm 0.24^{\mathrm{a}}$ & $1.08 \pm 0.10^{\mathrm{a}}$ & $0.91 \pm 0.21^{\mathrm{a}}$ & $0.13 \pm 0.01^{b}$ \\
\hline & IC & $1.1 \pm 0.26^{\mathrm{a}}$ & $1.56 \pm 0.46^{\mathrm{a}}$ & $0.71 \pm 0.33^{\mathrm{a}}$ & $0.77 \pm 0.02^{\mathrm{a}}$ \\
\hline
\end{tabular}

Data of each parameter within each plant species indicated by the same letter are not statistically different $(p<0.05)$.

Shoot and root $\mathrm{P}$ content decreased by IC in wheat, while increased in sugar beet. This effect, however, was not statistically significant in $\mathrm{P}$-deficient sugar beet. $\mathrm{P}$ content was expectedly lower in low $\mathrm{P}$ plants in both species irrespective the cultivation system (Fig. 2). 

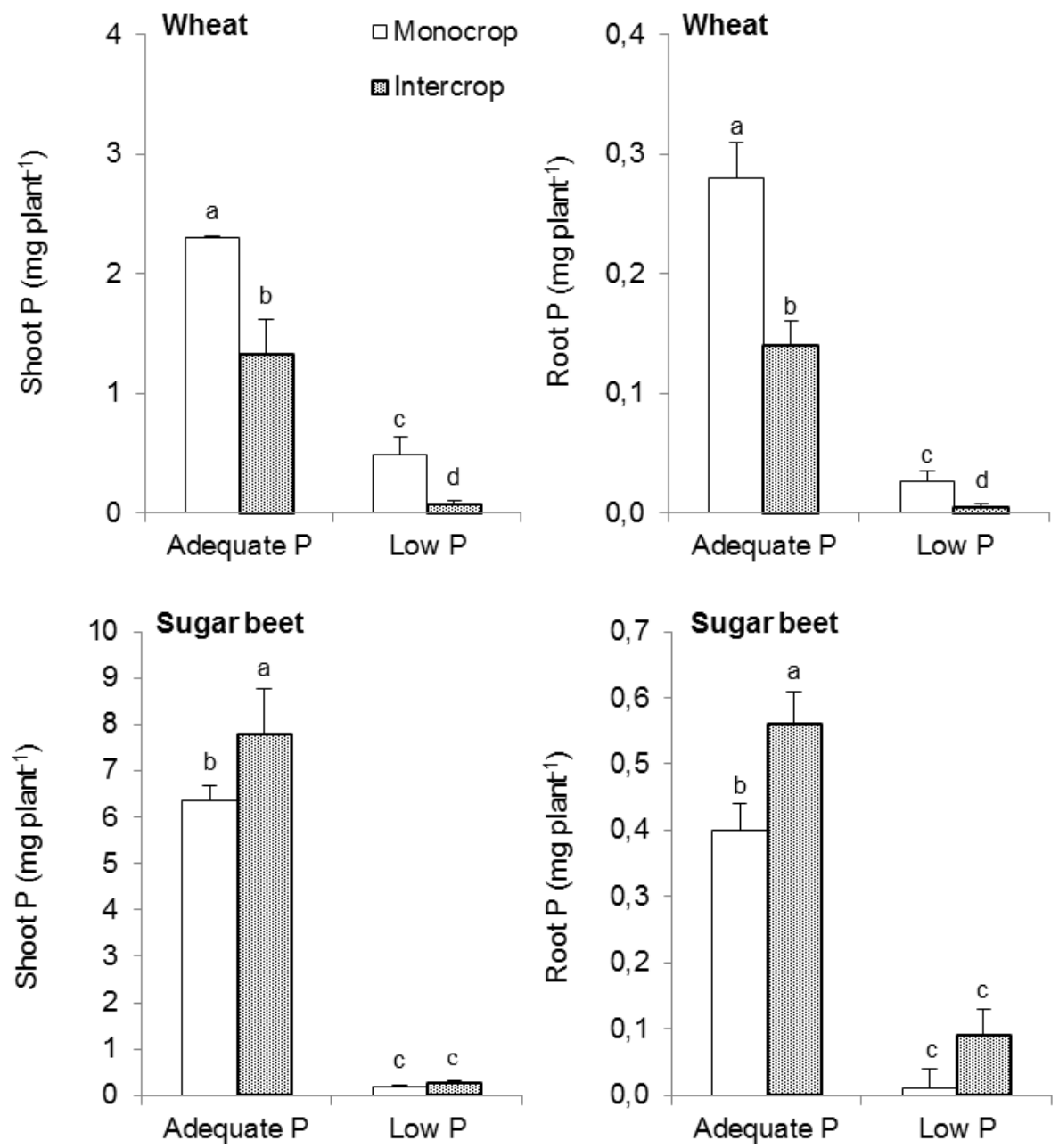

Figure 2: Phosphorus content in the shoot and roots of wheat and sugar beet plants in monocropping and intercropping under adequate or low $\mathrm{P}$ supply. Bars indicated by the same letter are not statistically different $(p<$ $0.05)$.

Similar to $\mathrm{P}$, K contents were decreased in IC wheat while increased in sugar beet in both shoot and roots (Fig. 3). In both species P-deficient plants had significantly lower shoot $\mathrm{K}$ content under both $\mathrm{MC}$ and IC conditions. In the roots, this effect was significant only in sugar beet under IC conditions (Fig. 3). 

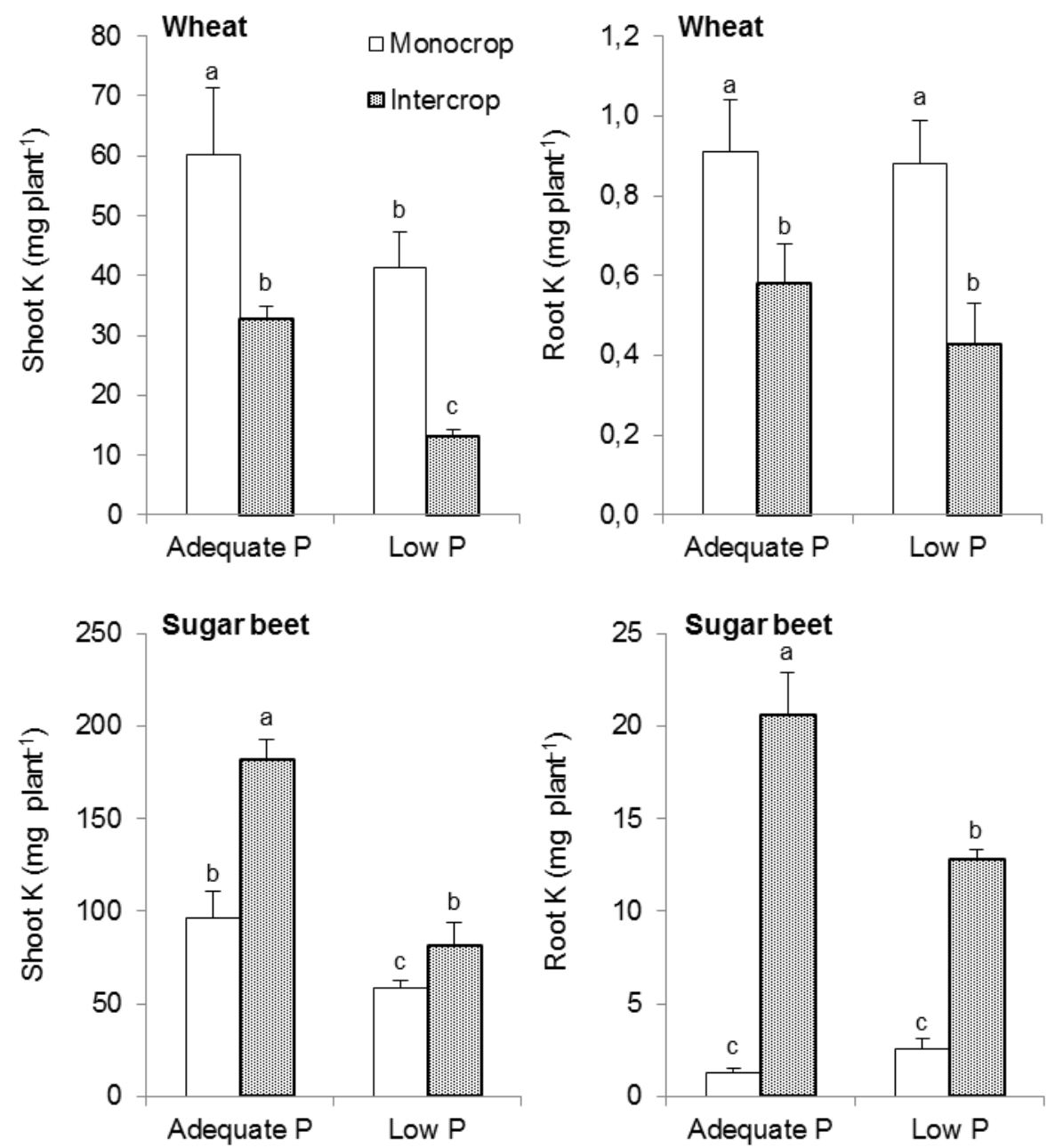

Figure 3: Potassium content in the shoot and roots of wheat and sugar beet plants in monocropping and intercropping under adequate or low $\mathrm{P}$ supply. Bars indicated by the same letter are not statistically different $(p<$ 0.05).

$\mathrm{P}$ deficiency decreased shoot Fe content in both species under MC conditions (Fig. 4). A similar effect of low P was observed on root $\mathrm{Fe}$ only in $\mathrm{MC}$ wheat, while in $\mathrm{MC}$ sugar beet root $\mathrm{Fe}$ contents were significantly higher in low $\mathrm{P}$ plants. Intercropping influenced $\mathrm{Fe}$ content differently depending on $\mathrm{P}$ nutrition and plant species. In wheat, IC plants had lower Fe contents under adequate but not under low $\mathrm{P}$ supply. Contrastingly, Pdeficient, but not P-sufficient sugar beet plants had significantly higher Fe contents in both shoot and root when intercropped with wheat. Significant reduction of root Fe was also found in sugar beet upon IC (Fig. 4). 

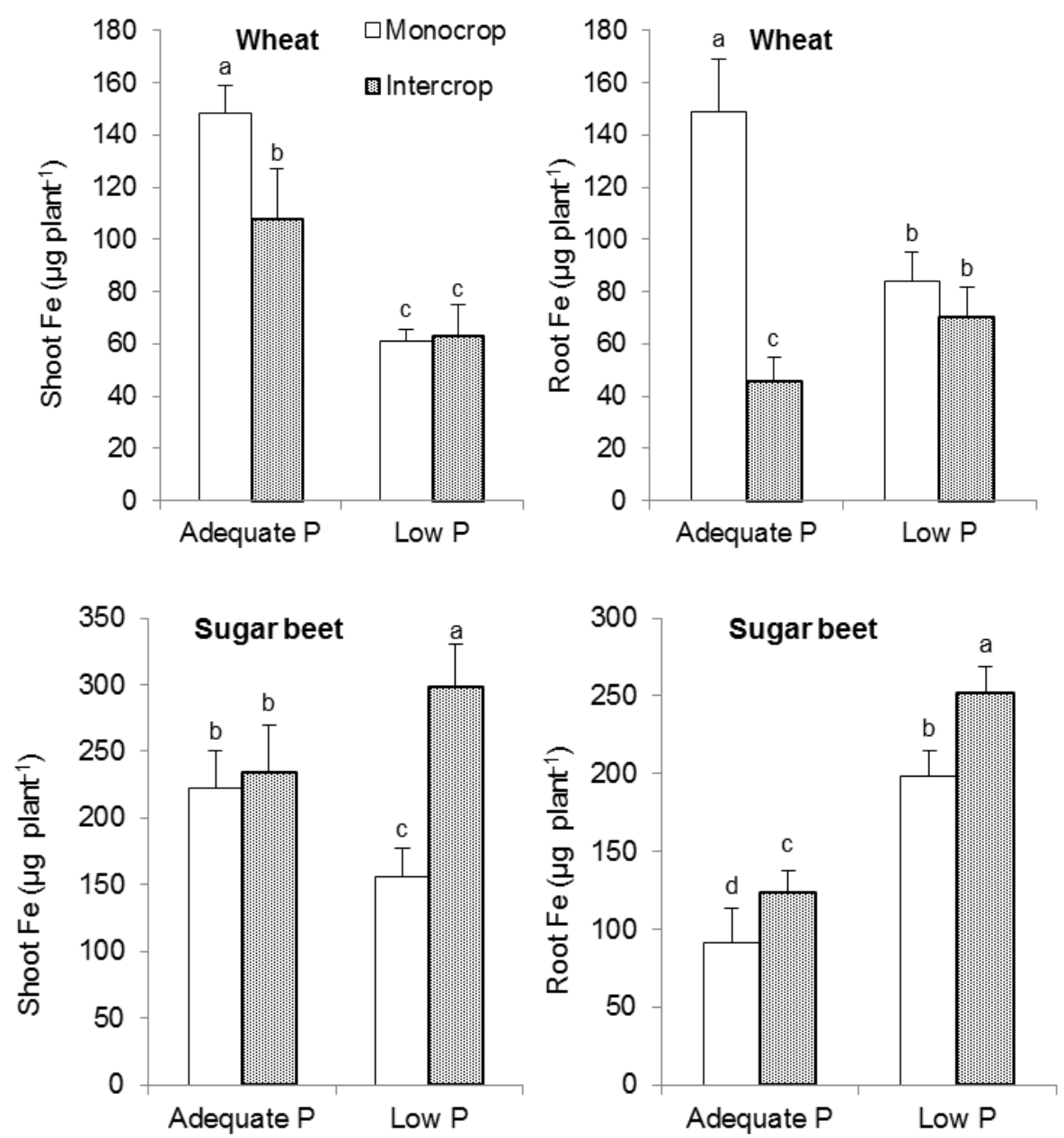

Figure 4: Iron content in the shoot and roots of wheat and sugar beet plants in monocropping and intercropping under adequate or low P supply. Bars indicated by the same letter are not statistically different $(p<0.05)$.

Rhizosphere $\mathrm{pH}$ was decreased under $\mathrm{P}$ deficiency conditions in sugar beet in both MC and IC systems, while in wheat this effect was observed only in IC pots. Intercropping increased the rhizosphere $\mathrm{pH}$ in sugar beet while decreased it in wheat (Table 4). Root activity of acid phosphatase was expectedly higher in low $\mathrm{P}$ plants. However, this effect was not significant in wheat under MC (Table 4). Intercropped plants had significantly higher ACPase activity under both $\mathrm{P}$ supply levels, the highest activity was observed in IC sugar beet under low P conditions (Table 4).

Table 4: Rhizosphere $\mathrm{pH}$ and root activity of acid phosphatase (APase, $\mu \mathrm{mol}$ PNP $\min ^{-1} \mathrm{~g}^{-1}$ root DM) in wheat and sugar beet plants in monocropping (MC) or intercropping (IC) in perlite at adequate or low P supply for 10 weeks under controlled environmental conditions.

\begin{tabular}{llllll}
\hline Plant & Culture & \multicolumn{3}{l}{ Rhizosphere pH } & APase activity \\
\cline { 3 - 6 } species & mode & Adequate P & Low P & Adequate P & Low P \\
\hline \multirow{2}{*}{ Wheat } & MC & $7.50 \pm 0.01^{\mathrm{a}}$ & $7.47 \pm 0.14^{\mathrm{a}}$ & $3.35 \pm 0.56^{\mathrm{c}}$ & $3.94 \pm 0.69^{\mathrm{c}}$ \\
& IC & $7.15 \pm 0.03^{\mathrm{b}}$ & $6.89 \pm 0.02^{\mathrm{c}}$ & $7.35 \pm 1.75^{\mathrm{b}}$ & $12.13 \pm 1.44^{\mathrm{a}}$ \\
\hline \multirow{2}{*}{ Sugar beet } & MC & $6.70 \pm 0.17^{\mathrm{b}}$ & $6.48 \pm 0.05^{\mathrm{c}}$ & $8.59 \pm 1.07^{\mathrm{c}}$ & $16.44 \pm 3.21^{\mathrm{b}}$ \\
& IC & $7.19 \pm 0.01^{\mathrm{a}}$ & $6.82 \pm 0.04^{\mathrm{b}}$ & $10.6 \pm 0.42^{\mathrm{c}}$ & $24.97 \pm 4.57^{\mathrm{a}}$
\end{tabular}

Data of each parameter within each plant species indicated by the same letter are not statistically different $(p<0.05)$. 
Extraction of nutrients calculated as the total nutrient content of plants in each pot showed different capacity of species and its modification by IC. Under adequate P supply, $\mathrm{P}$ extraction ability was higher in sugar beet than wheat and $\mathrm{P}$ extraction from IC pots stood between wheat and sugar beet MC pots. At low $\mathrm{P}$ supply, in contrast, $\mathrm{P}$ extraction in $\mathrm{MC}$ wheat pots was higher than both MC sugar beet and IC pots (Table 5). K extraction was higher in sugar beet than wheat under $\mathrm{MC}$ conditions and $\mathrm{P}$ supply level did not change it. Plants in IC pots had significantly higher $\mathrm{P}$ extraction at adequate but not low P supply. Higher Fe extraction was observed in sugar beet than wheat at both $\mathrm{P}$ supply levels, while effect of IC depended on P supply level. Slightly higher Fe extraction in IC pots than both MC pots was observed at low but not adequate $\mathrm{P}$ supply level (Table 5).

Table 5: Extraction of $\mathrm{P}\left(\mathrm{mg} \mathrm{pot}^{-1}\right), \mathrm{K}\left(\mathrm{mg} \mathrm{pot}^{-1}\right)$ and $\mathrm{Fe}\left(\mu \mathrm{g} \operatorname{pot}^{-1}\right)$ from the growth medium in wheat and sugar beet plants in monocropping (MC) or intercropping (IC) in perlite at adequate or low $\mathrm{P}$ supply for 10 weeks under controlled environmental conditions.

\begin{tabular}{lllllll}
\hline & $\mathbf{P}$ & \multicolumn{3}{c}{ K } & Fe \\
\cline { 2 - 6 } & Adequate P & Low P & Adequate P & Low P & Adequate P & Low P \\
\hline Wheat MC & $9.47 \pm 1.28^{\mathrm{c}}$ & $2.02 \pm 0.59^{\mathrm{a}}$ & $243 \pm 65^{\mathrm{b}}$ & $170 \pm 22^{\mathrm{b}}$ & $993 \pm 43^{\mathrm{b}}$ & $706 \pm 77^{\mathrm{b}}$ \\
Sugar beet MC & $26.89 \pm 4.22^{\mathrm{a}}$ & $0.92 \pm 0.22^{\mathrm{b}}$ & $393 \pm 59^{\mathrm{a}}$ & $246 \pm 10^{\mathrm{a}}$ & $1497 \pm 171^{\mathrm{a}}$ & $922 \pm 120^{\mathrm{a}}$ \\
Intercropping & $19.65 \pm 4.72^{\mathrm{b}}$ & $0.80 \pm 0.14^{\mathrm{b}}$ & $457 \pm 22^{\mathrm{a}}$ & $172 \pm 50^{\mathrm{b}}$ & $850 \pm 162^{\mathrm{b}}$ & $1091 \pm 181^{\mathrm{a}}$ \\
\hline
\end{tabular}

Data of each column indicated by the same letter are not statistically different $(p<0.05)$.

Similar effects of IC on biomass and nutrients uptake were observed in plants grown for one week under hydroponic conditions. Fresh and dry biomass as well as $\mathrm{P}$ and $\mathrm{K}$ content were decreased in wheat by IC, while that of sugar beet increased (Table 6). Ten weeks after growth in hydroponic medium, biomass of wheat was less affected by culture mode while in sugar beet it was higher in IC compared to MC pots (Table 6). In general, effect of culture mode was less expressed in this experiment compared to the long term experiment $(2.5$ months) on perlite substrate. 
Table 6: Shoot and root fresh $\left(\mathrm{g}\right.$ plant $\left.{ }^{-1}\right)$ and dry $\left(\mathrm{mg}\right.$ plant $\left.^{-1}\right)$ mass and content of $\mathrm{P}\left(\mu \mathrm{g}\right.$ plant $\left.^{-1}\right)$ and $\mathrm{K}\left(\mathrm{mg}\right.$ plant $\left.{ }^{-1}\right)$ in wheat and sugar beet plants grown hydroponically in monocropping (MC) or intercropping (IC) system for one or 10 weeks under controlled environmental conditions.

\begin{tabular}{|c|c|c|c|c|c|}
\hline \multirow{3}{*}{$\begin{array}{l}\text { Plant } \\
\text { species }\end{array}$} & \multirow{3}{*}{$\begin{array}{l}\text { Culture } \\
\text { mode }\end{array}$} & \multicolumn{4}{|l|}{ One week } \\
\hline & & \multicolumn{2}{|l|}{ Fresh mass } & \multicolumn{2}{|l|}{ Dry mass } \\
\hline & & Shoot & Root & Shoot & Root \\
\hline \multirow{2}{*}{ Wheat } & MC & $0.50 \pm 0.08^{\mathrm{a}}$ & $0.20 \pm 0.02^{\mathrm{a}}$ & $59 \pm 7^{\mathrm{a}}$ & $14 \pm 1.2^{\mathrm{a}}$ \\
\hline & IC & $0.32 \pm 0.05^{b}$ & $0.23 \pm 0.06^{\mathrm{a}}$ & $40 \pm 4^{b}$ & $12 \pm 3.5^{\mathrm{a}}$ \\
\hline \multirow{4}{*}{ Sugar beet } & $\mathrm{MC}$ & $10.2 \pm 2.5^{b}$ & $1.38 \pm 0.42^{b}$ & $413 \pm 159^{a}$ & $83 \pm 8^{b}$ \\
\hline & IC & $16.0 \pm 2.6^{\mathrm{a}}$ & $2.52 \pm 0.14^{\mathrm{a}}$ & $538 \pm 193^{a}$ & $126 \pm 28^{a}$ \\
\hline & & $\mathbf{P}$ & & $\mathbf{K}$ & \\
\hline & & Shoot & Root & Shoot & Root \\
\hline \multirow{2}{*}{ Wheat } & $\mathrm{MC}$ & $63 \pm 9.0^{\mathrm{a}}$ & $15 \pm 1.8^{\mathrm{a}}$ & $4.39 \pm 0.53^{\mathrm{a}}$ & $0.50 \pm 0.10^{\mathrm{a}}$ \\
\hline & IC & $44 \pm 0.5^{\mathrm{b}}$ & $6 \pm 1.4^{\mathrm{b}}$ & $2.07 \pm 0.34^{\mathrm{b}}$ & $0.15 \pm 0.01^{b}$ \\
\hline \multirow{5}{*}{ Sugar beet } & $\mathrm{MC}$ & $345 \pm 65^{b}$ & $55 \pm 18^{\mathrm{a}}$ & $26 \pm 9^{b}$ & $1.9 \pm 0.40^{\mathrm{a}}$ \\
\hline & IC & $709 \pm 168^{a}$ & $70 \pm 21^{\mathrm{a}}$ & $55 \pm 16^{\mathrm{a}}$ & $2.5 \pm 0.43^{\mathrm{a}}$ \\
\hline & & \multicolumn{4}{|l|}{10 weeks } \\
\hline & & \multicolumn{2}{|l|}{ Fresh mass } & \multicolumn{2}{|l|}{ Dry mass } \\
\hline & & Shoot & Root & Shoot & Root \\
\hline \multirow{2}{*}{ Wheat } & MC & $2.95 \pm 0.34^{\mathrm{a}}$ & $1.78 \pm 0.23^{\mathrm{a}}$ & $362 \pm 59^{\mathrm{a}}$ & $203 \pm 32^{\mathrm{a}}$ \\
\hline & IC & $2.01 \pm 0.22^{\mathrm{a}}$ & $1.27 \pm 0.11^{\mathrm{a}}$ & $265 \pm 33^{a}$ & $139 \pm 44^{\mathrm{a}}$ \\
\hline \multirow{2}{*}{ Sugar beet } & $\mathrm{MC}$ & $104 \pm 9.8^{b}$ & $16.9 \pm 2.67^{b}$ & $5552 \pm 840^{b}$ & $1024 \pm 168^{b}$ \\
\hline & IC & $127 \pm 2.8^{\mathrm{a}}$ & $23.7 \pm 1.65^{\mathrm{a}}$ & $7019 \pm 719^{a}$ & $2287 \pm 244^{\mathrm{a}}$ \\
\hline
\end{tabular}

Significant difference between MC and IC plants were indicated by different letters (t-test, $p<0.05$ ).

\section{DISCUSSION}

Research works on the dicotyledonous-cereals intercropping systems are focused on legume-cereals and to the best of our knowledge no study has been published on sugar beet-based intercropping and its comparison with legume-based systems. In this work intercropping system had distinctly different effect on dry matter production of wheat and sugar beet in parallel with differences in nutrient uptake and rhizosphere characteristics. In contrast to legumecereals intercropping systems in which both species benefit from the interaction ( $\mathrm{Li}$ et al., 2007; Zuo \& Zhang, 2009; Dissanayaka et al., 2015), in sugar beetwheat intercropping the growth of sugar beet was increased at the expense of wheat growth. Reduction of wheat growth in IC compared to MC pots was associated with changes in several parameters that may be either the cause or the consequence for the growth impairment in wheat. Although photosynthetic area in sugar beet was greater than wheat, the latter plants were held upright throughout the experiment using holders ensuring that sufficient light was captured in the growth chamber by wheat. Thus, it is likely that the observed intercropping effects are mainly caused by belowground interactions. To our best knowledge any allelopathic compound has not been isolated or identified in sugar beet.

\subsection{P and $K$ uptake under MC and IC conditions}

Competition for nutrients is responsible, at least in part, for the observed differences in the nutrient contents 
between sugar beet and wheat in IC pots. The data of $\mathrm{P}$ and $\mathrm{K}$ extraction from the medium in MC pots indicate that sugar beet had greater capacity for the uptake of $\mathrm{P}$ and $\mathrm{K}$ under both $\mathrm{P}$ supply levels (except for $\mathrm{P}$ at low $\mathrm{P}$ supply). It is thus likely that in IC pots, $\mathrm{P}$ and $\mathrm{K}$ were depleted faster by sugar beet in the time intervals of nutrient solution addition to the pots. This, accordingly, resulted in higher $\mathrm{P}$ and $\mathrm{K}$ contents in sugar beet in IC pots at the end of experiment. However, there are reasons against competition as the main cause for the observed difference between sugar beet and wheat in IC pots. $\mathrm{P}$ and $\mathrm{K}$ extraction rates were not higher in IC than MC pots implying that the nutrients limitation was not intensified upon IC. Under low $\mathrm{P}$ supply, in addition, total $\mathrm{P}$ extracted from the $\mathrm{MC}$ wheat pots was greater than MC sugar beet pots (Table 5) an indication of higher competition ability in wheat than sugar beet under $\mathrm{P}$ deficiency conditions. In agreement with this, and considering shoot biomass production in MC pots, wheat was more efficient under $\mathrm{P}$ deficiency conditions (25\% reduction) compared to sugar beet (48\% reduction). The enhancement of root length in response to $\mathrm{P}$ deficiency observed, but not in sugar beet, may account for this. It has been observed that under field conditions wheat has a large root system that compensates for low $\mathrm{P}$ influx when $\mathrm{P}$ availability is low, whereas sugar beet is able to achieve high $\mathrm{P}$ influx despite low P availability in soil (Bhadoria et al., 2002) mainly because of its ability for root release of citramalic acid and salicylic acid that solubilize and mobilize $\mathrm{P}$ in the soil (Khorassani et al., 2011). As related to other intercropping systems, it has been reported that in low $\mathrm{P}$ soils intercropping maize/faba bean and maize/white lupin resulted in an over yielding of both species through rhizosphere facilitation mechanisms (Li et al., 2007; Dissanayaka et al., 2015). An enhancement in P availability in the rhizosphere of both species in the legumes-cereals intercropping in low $\mathrm{P}$ soils has been attributed to an interspecific rhizosphere effect including acidification, exudation of carboxylates and greater phosphatase activity in the rhizosphere which mobilize insoluble soil $\mathrm{P}$, increase the availability of insoluble inorganic $\mathrm{P}$ and decompose soil organic $\mathrm{P}$ into an inorganic form which can be used by both species (Li et al., 2007). However, in our work we could not evaluate the effect of chemical modification of the rhizosphere by root exudates because of using soluble $\mathrm{P}$ in the medium and the observed differences could be only attributed to differences in the spatial availability and/or root uptake efficiency. Higher root length in sugar beet (130-170 m plant $^{-1}$ ) than wheat (80-90 m plant $\left.{ }^{-1}\right)$ in IC pots in contrast to the similar amounts in MC pots $(40-70 \mathrm{~m}$ plant $^{-1}$ ) may be considered one mechanism for higher nutrients content in sugar beet in IC pots. However, the same differences between two species observed in IC pots in the short term hydroponic experiment indicated that the role of root length and higher spatial availability could not be the sole mechanism for the higher $\mathrm{P}$ and $\mathrm{K}$ uptake capacity of sugar beet in IC pots.

\subsection{Iron uptake under MC and IC conditions}

Fe uptake capacity as evaluated by total Fe extracted from MC pots was higher in sugar beet than in wheat. This further implies higher competition ability of sugar beet for $\mathrm{Fe}$ acquisition from the medium. Greater $\mathrm{Fe}$ uptake in legume-gramineae intercropping has been reported under field conditions (Zuo \& Zhang, 2009). Different response mechanisms to Fe-deficiency stress between graminaceous and dicotyledonous species, i.e. strategy I (reduction strategy) in dicots and II (chelation strategy) in gramineae, has been considered the reason for greater $\mathrm{Fe}$ uptake in intercropping dicot/graminae systems in a wide range of soil $\mathrm{pH}$ values (Zuo \& Zhang, 2009; Li et al., 2014). Because no Fe deficiency was imposed to the plants in this experiment, we could not evaluate the effect of these mechanisms for $\mathrm{Fe}$ uptake. Shoot and root Fe content in wheat decreased under IC conditions under adequate, but not under low $\mathrm{P}$ supply. This result suggests a positive effect of $\mathrm{P}$ deficiency on the $\mathrm{Fe}$ acquisition capacity in wheat alleviating their reduction of Fe uptake caused by IC in this species. The decrease of rhizosphere $\mathrm{pH}$, an important mechanisms for facilitation of $\mathrm{Fe}$ mobilization and uptake (Neumann \& Römheld, 2012), that was observed more at low $\mathrm{P}(\mathrm{pH}$ 6.89) compared to adequate $\mathrm{P}(\mathrm{pH} 7.15)$ conditions in wheat grown in IC pots could be a probable reason for the different effects of IC under low and adequate $\mathrm{P}$ conditions.

\subsection{Biochemical parameters under MC and IC conditions}

Leaf pigments decreased in IC wheat while remained unchanged in sugar beet. Reduction of Fe content (or concentration, data not shown) could explain partly reduction of $\mathrm{Chl}$ in IC compared to $\mathrm{MC}$ wheat plants under adequate, but not under low $\mathrm{P}$ supply. Net assimilation rate was consistently lower in IC wheat while increased in IC sugar beet compared with their corresponding MC plants. Although effects of IC on P, $\mathrm{K}$ and $\mathrm{Fe}$ on the corresponding changes in the photosynthesis rate could not be ruled out, other interspecific interactions were also likely important players in this regard. Interestingly, transpiration rate was lower in both species under IC conditions suggesting the influence of IC on stomatal behavior. Greater leaf area and transpiration surface in IC pots because of the presence of sugar beet may be the reason for faster water depletion in IC compared to MC wheat pots. Nonetheless, more closed stomata and a similar decrease in transpiration rate of sugar beet in IC pots suggests that water status of the substrate was only partly involved in reduction of transpiration rate in IC 
plants. Reduction of transpiration rate concomitant with higher photosynthesis rate resulted in a significantly higher WUE in IC sugar beet that may be of high importance under field conditions during a long growth season. Effect of intercropping on plants photosynthesis rate has not yet been reported. However, there are reports on both higher (Yang et al., 2011) and lower (Gao et al., 2009) WUE in intercropping systems compared to monocropping under field conditions. This implies a complex interaction between rooting depth, water extraction capacity and transpiration surface area in intercropping systems.

Unexpectedly, IC-mediated changes in the soluble sugars concentrations were not correlated with the photosynthesis rate and they were consistently higher in IC conditions in both species. Accumulation of soluble sugars in IC wheat though reduction of photosynthesis rate may be a sign for sink limitation in this species. In addition, higher soluble carbohydrates in the roots may be the reason for higher root length of IC plants. Higher soluble sugars allocation to the roots has been observed under $\mathrm{P}$ limitation and $\mathrm{P}$ availability is a key regulator of many aspects of root growth and development, including root hair length and density, elongation, secondary development, branching and adventitious rooting (Niu et al., 2013). The preferential allocation of $\mathrm{C}$ to the root system, and the resulting increased root/shoot biomass ratio, appears to be a direct consequence of altered shoot metabolism and is mediated by increased translocation of sucrose to the root (Hammond \& White, 2008; Chiou \& Lin, 2011). In addition, the sucrose delivered to the root acts as a systemic signal (indicating low shoot $\mathrm{P}$ status) that can initiate changes in gene expression to alter root biochemistry and remodel root morphology (Niu et al., 2013; Lin et al., 2014). Increased root sucrose concentrations appear to upregulate genes encoding phosphatases and other metabolic enzymes in combination with the PHR1 transcriptional cascade, whilst its effects on lateral rooting occur through modulation of auxin transport (Hammond \& White, 2008; Rouached et al., 2010). This mechanism could be responsible for higher carbohydrates associated with greater root length in $-\mathrm{P}$ compared with $+\mathrm{P}$ wheat (but not sugar beet) irrespective the cultivation mode. However, higher carbohydrate allocation to the roots and greater root length under IC conditions is unlikely to have occurred through triggering P deficiency in both species because $\mathrm{P}$ extraction rate was not enhanced upon IC conditions. It is likely that interspecific interactions under IC conditions are mediated by the same signaling pathway of $\mathrm{P}$ deficiency that in turn triggered similar responses in both species.

Reduction of amino acids and soluble proteins in IC wheat compared to MC indicated lower $\mathrm{N}$ uptake and/or assimilation under these conditions. Nitrogen was not analyzed in this work, but the same mechanisms for $\mathrm{P}$ and $\mathrm{K}$ as the important anion and cation was also expected for $\mathrm{NO}_{3}^{-}$and $\mathrm{NH}_{4}{ }^{+}$in the medium. Correlation between $\mathrm{N}$ nutrition and plant growth response to IC may indicate an important role of $\mathrm{N}$ in determining plants growth under IC but it does not indicate necessarily a competition between sugar beet and wheat in IC conditions and the contribution of an interspecific interaction like for other nutrients could not be ruled out.

\subsection{Rhizosphere properties under MC and IC conditions}

Decrease of rhizosphere $\mathrm{pH}$ in IC wheat and its increase in IC sugar beet compared with their corresponded MC pots was expected because of a known difference between monocot and dicot species in the cation/anion uptake ratio and frequently reported difference between these plants in the ability for modification of rhizosphere $\mathrm{pH}$. Nutrient uptake is closely coupled to uptake or release of protons and therefore frequently associated with root-induced changes in rhizosphere $\mathrm{pH}$. Due to differences in plant requirements and also in the availability of nutrients, uptake of cations and anions is often not balanced. Excess uptake of cations is balanced by a net release of protons and consequently leads to rhizosphere acidification (Neumann \& Römheld, 2012). It has been observed that faba bean acidified its rhizosphere intensivelly, in contrast, maize alkalized its rhizosphere (Li et al., 2007). Effect of modifications in the rhizosphere $\mathrm{pH}$ on $\mathrm{Fe}$ and $\mathrm{P}$ uptake capacity in IC conditions was discussed above.

Root activity of secreted acid phosphatase was higher in IC plants of both species irrespective the $\mathrm{P}$ nutritional status. A well-documented component of the plant Pi stress response is the up-regulation of both intracellular and secreted acid phosphatases (APases; E.C. 3.1.3.2) that catalyze the hydrolysis of $\mathrm{Pi}$ from various phosphate monoesters and anhydrides in the acidic $\mathrm{pH}$ range (Rouached et al., 2010; Chiou \& Lin, 2011). It has been shown that a decrease of local, external $\mathrm{Pi}$ availability is sufficient to induce AtPAP10 transcription, one of the secreted ACPase in roots in the presence of sucrose as a systemic signal from shoots and only the magnitude of the induction is affected by the Pi status of the whole plant (Zhang et al., 2014). Although we did not determine Pi in the substrate in this work, the $\mathrm{P}$ extraction rate during whole growth period as an indication of $\mathrm{P}$ depletion in the pots was not higher in IC compared to MC pots, excepting for wheat under adequate $\mathrm{P}$. However, it is likely that, a temporary $P$ deficiency has been induced in IC pots in the time intervals between application of nutrient solution due to a greater uptake capacity of sugar beet. Nevertheless, regarding an immediate effect of $\mathrm{Pi}$ in down regulation 
of ACPase (Rouached et al., 2010; Chiou \& Lin, 2011) and the absence of a significant ACPase induction in the P-deficient wheat plants in MC pots, it seems unlikely that IC conditions induced $\mathrm{P}$ deficiency in our experiment. Molecular analyses of transcripts and proteins have hinted at complex control of plant APase gene expression. It has been demonstrated that $\mathrm{Pi}$ deprivation induces temporal and tissue-specific expression of -Pi-inducible APase isozymes and the concomitant downregulation of other APases (Misson et al., 2005). The purple APases (PAPs) as the largest class of nonspecific plant APases have a complex structure variation and expression regulation, so that gene transcription of two PAPs (AtPAP11 and AtPAP12) was induced and increased, respectively, whereas that of the remaining five AtPAPs was not affected by phosphate deprivation ( $\mathrm{Li}$ et al., 2002). It is plausible that IC conditions induced some of PAPs that are not responsive to $\mathrm{P}$ nutritional status or $\mathrm{Pi}$ in the medium and is triggered by other factors that in turn were modified by intercropping and particular yet unknown plant-plant interactions. Greater ACPase activity in both species may have important consequences on low $\mathrm{P}$ soils under field conditions for plants grown as IC.

\section{CONCLUSION}

Reduction of $\mathrm{P}, \mathrm{K}$ and $\mathrm{Fe}$ content, leaf pigments, photosynthesis rate, amino acids and protein contents was observed in IC wheat while these parameters were improved or remained stable in IC sugar beet. Indeed under IC conditions facilitative interaction for sugar beet was occurred at the expense of wheat and an increase in the ability for more efficient use of resources for both species was not observed in this work. The existence of three characteristic responses of plant to $\mathrm{P}$ deficiency in both species even at adequate P supply (higher root length, accumulation of carbohydrates and upregulation of secretory ACPase activity) implied likely that a signaling pathway similar with the response induced by Pi starvation, is triggered by intercropping in both species. Our results present an example of direct interspecific interaction, but unfortunately, we fail to fully explore the nature of it and further investigations are needed for unraveling the involving mechanisms.

\section{REFERENCES}

Bagayoko, M., Alvey, S., Neumann, G., Buerkert, A. (2000). Root-induced increases in soil $\mathrm{pH}$ and nutrient availability to field-grown cereals and legumes on acid sandy soils of Sudano-Sahelian West Africa. Plant and Soil, 225, 117-127. doi:10.1023/A:1026570406777

Bhadoria, P. B. S., Steingrobe, B., Claassen, N., Leibersbach, H. (2002). Phosphorus efficiency of wheat and sugar beet seedlings grown in soils with mainly calcium, or iron and aluminium phosphate. Plant and Soil, 264, 41-52. doi:10.1023/A:1021567331637

Brooker, R. W., Maestre, F. T., Callaway, R. M., Lortie, C. T., Cavieres, L. A., Kunstler, G., Liancourt, P., Tielbbörger, K., Travis, J. M. J., Anthelme, F., Armas, C., Coll, L., Corcket, E., Delzon, S., Forey, E., Kikvidze, E., Olofsson, J., Pugnaire, F., Quiroz, C. L., Saccone, P., Schiffers, K., Seifan, M., Touzard, B., Michalet, B. (2008). Facilitation in plant communities: the past, the present, and the future. Journal of Ecology, 96, 18-34.

Brooker, R. W., Bennett, A. E., Cong, W. F., Daniell, T. J., George, T. S., Hallett, P. D., Hawes, C., Iannetta, P. P. M., Jones, H. G., Karley, A. J., Li, L., Mc Kenzie, B. M., Pakeman, R. J., Paterson, E., Schöb, C., Shen, J., Squire, G., Watson, C. A., Zhang, C.,
Zhang, F., Zhang, J., White, P. J. (2015). Improving intercropping: a synthesis of research in agronomy, plant physiology and ecology. New Phytologists, 206, 107-117. doi:10.1111/nph.13132

Chiou, T. J., Lin, S. I. (2011). Signaling network in sensing phosphate availability in plants. Annual Review of Plant Biology, 62, 185-206. doi:10.1146/annurev-arplant-042110-103849

Dissanayaka, D. M. S. B., Maruyama, H., Masuda, G., Wasaki, J. (2015). Interspecific facilitation of $\mathrm{P}$ acquisition in intercropping of maize with white lupin in two contrasting soils as influenced by different rates and forms of $\mathrm{P}$ supply. Plant and Soil, 390, 223-236. doi:10.1007/s11104-015-2392$\mathrm{x}$

Gao, Y., Duan, A., Sun, J., Li, F., Liu, Z., Liu, H., Liu, Z. (2009). Crop coefficient and water-use efficiency of winter wheat/spring maize strip intercropping. Field Crops Research, 111, 65-73. doi:10.1016/j.fcr.2008.10.007

Hammond, J. P., White, P. J. (2008). Sucrose transport in the phloem: integrating root responses to phosphorus starvation. Journal of Experimental Botany, 59, 93-109. doi:10.1093/jxb/erm221 
Hawkesford, M., Horst, W., Kichey, T., Lambers, H., Schjoerring, J., Skrumsager, I., White, P. (2012). Function of macronutrients. In Marschner, P. (Ed.), Marschner's Mineral Nutrition of Higher Plants (pp. 135-472). London, UK: Academic Press. doi:10.1016/B978-0-12-384905-2.00006-6

Jaiswal, P. C. (2003). Soil, Plant and Water Analysis. Ludhiana, India: Kalyani Publishers.

Khorassani, R., Hettwer, U., Ratzinger, A., Steingrobe, B., Karlovsky, P., Claassen, N. (2011). Citramalic acid and salicylic acid in sugar beet root exudates solubilize soil phosphorus. BMC Plant Biology, 11, 1. doi:10.1186/1471-2229-11-121

Li, L., Li, S. M., Sun, J. H., Zhou, L. L., Bao, X. G., Zhang, H. G., Zhang, F. S. (2007). Diversity enhances agricultural productivity via rhizosphere phosphorus facilitation on phosphorus-deficient soils. Proceedings of the National Academy of Sciences (USA), 104, 11192-11196. doi:10.1073/pnas.0704591104

Li, L., Tilman, D., Lambers, H., Zhang, F. S. (2014). Plant diversity and overyielding: insights from below-ground facilitation of intercropping in agriculture. New Phytologists, 203, 63-69. doi:10.1111/nph.12778

Li, D., Zhu, H., Liu, K., Liu, X., Leggewie, G., Udvardi, M., Wang, D. (2002). Purple acid phosphatases of Arabidopsis thaliana comparative analysis and differential regulation by phosphate deprivation. Journal of Biological Chemistry, 277, 2777227781. doi:10.1074/jbc.M204183200

Lichtenthaler, H. K., Wellburn, A. R. (1985). Determination of total carotenoids and chlorophylls $\mathrm{a}$ and $\mathrm{b}$ of leaf in different solvents. Biochemical Society Transactions, 11, 591-592. doi:10.1042/bst0110591

Lin, W. Y, Huang, T. K., Leong, S. J., Chiou, T. J. (2014). Long-distance call from phosphate: systemic regulation of phosphate starvation responses. Journal of Experimental Botany, 65, 1817-1827. doi:10.1093/jxb/ert431

Misson, J., Raghothama, K. G., Jain, A., Jouhet, J., Block, M. A., Bligny, R., Ortet, P., Creff, A., Somerville, S., Rolland, N., Doumas, P., Nacry, P., Herrerra-Estrella, L., Nussaume, L., Thibaud, M. C. (2005). A genome-wide transcriptional analysis using Arabidopsis thaliana Affymetrix gene chips determined plant responses to phosphate deprivation. Proceedings of the National Academy of Sciences (USA), 102, 11934-11939. doi:10.1073/pnas.0505266102

Neumann, G., Römheld, V. (2012). Rhizosphere chemistry in relation to plant nutrition. In:
Marschner, P. (Ed.), Marschner's Mineral Nutrition of Higher Plants (pp. 347-368). London, UK: Academic Press. doi:10.1016/B978-0-12-3849052.00014-5

Niu, Y. F., Chai, R. S., Jin, G. L., Wang, H., Tang, C. X., Zhang, Y. S. (2013). Responses of root architecture development to low phosphorus availability: a review. Annals of Botany, 112, 39140. doi:10.1093/aob/mcs285

Rouached, H., Arpat, A. B., Poirier, Y. (2010). Regulation of phosphate starvation responses in plants: signaling players and cross-talks. Molecular Plant, 3, 288-299. doi:10.1093/mp/ssp120

Wang, Z., Shen, J., Ludewig, U., Neumann, G. (2015). A re-assessment of sucrose signaling involved in cluster-root formation and function in phosphatedeficient white lupin (Lupinus albus). Physiologia Plantarum, 154, 407-419. doi:10.1111/ppl.12311

Wu, K., Fullen, M. A., An, T., Fan, Z., Zhou, F., Xue, G., Wu, B. (2012). Above-and below-ground interspecific interaction in intercropped maize and potato: A field study using the 'target' technique. Field Crops Research, 139, 63-70. doi:10.1016/j.fcr.2012.10.002

Yang, C., Huang, G., Chai, Q., Luo, Z. (2011). Water use and yield of wheat/maize intercropping under alternate irrigation in the oasis field of northwest China. Field Crops Research, 124, 426-432. doi:10.1016/j.fcr.2011.07.013

Yemm, E. W., Cocking, E. C. (1955). The determination of amino acids with ninhydrin. Analyst, 80, 209-213. doi:10.1039/an9558000209

Yemm, E. W., Willis, A. J. (1954). The estimation of carbohydrates in plant extracts by anthrone. Biochemistry Journal, 57, 508-514. doi:10.1042/bj0570508

Zhang, Y., Wang, X., Lu, S., Liu, D. (2014). A major root-associated acid phosphatase in Arabidopsis, AtPAP10, is regulated by both local and systemic signals under phosphate starvation. Journal of Experimental Botany, 65, 6577-6588. doi:10.1093/jxb/eru377

Zhang, F., Li, L. (2003). Using competitive and facilitative interactions in intercropping systems enhances crop productivity and nutrient-use efficiency. Plant and Soil, 248, 305-312. doi:10.1023/A:1022352229863

Zhang, F., Shen, J., Zhang, J., Zuo, Y., Li, L., Chen, X. (2010). Rhizosphere processes and management for improving nutrient use efficiency and crop productivity: implications for China. Advances in 
Roghieh HAJIBOLAND et al.

Agronomy, 107, 1-32. doi:10.1016/S00652113(10)07001-X

Zhang, F. S., Li, L., Sun, J. H. (2001). Contribution of above- and below-ground interactions to intercropping. In Horst, W. J., Schenk, M. K., Bürkert, A., Claassen, N., Flessa, H., Frommer, W. B., Goldbach, H., Olfs, H. W., Römheld, V., Sattelmacher, B., Schmidhalter, U., Schubert, S.,
Wirén, N. v., Wittenmayer, L., (Eds.), Plant Nutrition, Volume 92, Developments in Plant and Soil Sciences (pp. 978-979). Netherlands: Springer.

Zuo, Y., Zhang, F. (2009). Iron and zinc biofortification strategies in dicot plants by intercropping with gramineous species: a review. Agronomy for Sustainable Development, 29, 63-71. doi:10.1051/agro:2008055 